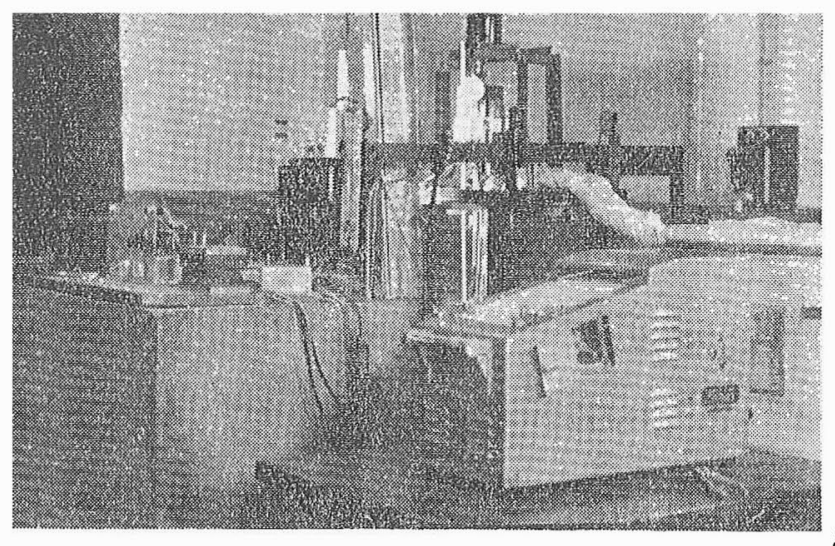

1.はじめに

A： 実験室をみせていたでいてありがとうございま した。感想を率直に申しあげると，結晶性高分子の非線 型粘弾性は実用的にる重要な問題で，会社ではごこでる 万能引張試験機を備え連日試験を行なっているはずで, 今さらこんなちゃちな装置でデータを出す必要があるか ということが最初に浮かんだことがらです。

B：たしかに誰でもいだく疑問だと思います。しか しこのような手つくりの装置でなんらかの仕事のできる のは, 結晶性高分子の非線型粘弹性が体系化されていな いこと，極端ないい方をすればまだ学問になっていない ためとい壳るでしょう。

A：結晶性高分子の非線型粘弾性が体系化されてな いというのはどのようなことですか。

B：それには無定形高分子の線型粘弾性がどのよう に整理されてきたかといらことを方りか党ってみればよ いと思います。粘弾性の实験には, 試料の下端におるり を下げて時間とともにのびがどのよ 5 亿変化するかを調 ベるクリープの実験，一定伸張を与兄て時間ととるに応 カがどのように変化していくかる調べる応力緩和の実 験, 一端を周期的に振動させて他端の応力を調べる動的 な測定なぞがあります。これらの実験は緩和機構を異な った方向からみているもので，それぞれの間に関係が存 在するはずであり采すこれらの関係は線型物理学に打 ける刺激応答の理論とよばれるもので, 古くから Gross ${ }^{1)}$ などにより数学的になとらめれています。それにしてる， たと克ば忍力緩和の実験で, 1 年しても10 年しても応 力緩和は続くわけであるから緩和の全ぼうを知ろうとす るとたいれんなことになります。この場合の指尊原理と

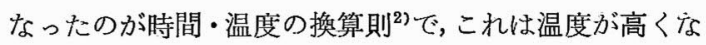
ると試料の粘度が下り, 緩和が早く起こるため, あたか も低速度カメラでうつした写真をみるように，低温に和 ける長時間後のありさ妾短時間のらちに知ることがで きるといら原理であります。この原理と N.B.S. とより

\footnotetext{
* 久留米工業短期大学教授 $\cdot$ 理博

** 同大学
}

\section{結晶性高分子の 非線型粘弾性}

\author{
竹村哲男* 黒木仁昭**
}

配布された標準試料により無定形高分子の緩和つ全社5 がわかったわ恬です。艺れととるに緩和の機構の大体の

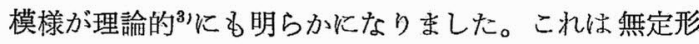
高分子の主要な緩和機構が 1 個の分子の緩和機構で近似 できることに原因があったわけです。

ところが結晶性高分子については，線型の性質につい てすら整理が十分でありません。これは結晶性高分子の 構造が複雑であり, 無定形高分子の緩和譏構の解明に役 立った1分子近似の取扱が全然できないこと原因する ものです。実際, 結晶性高分子の形態学的な研究でみら れるよらに文，折りたたまれた分子から成る結晶のラメ ラー構造は無定形高分子の状態とは全く異なるもので, むしろ金属のモザイク構造に近いるのであり恋す。かつ また簡単な熱処理により結晶の厚さが変わりらることは 結晶自身が非常にやわらかいことを示すむので，これら が結晶性高分子の特幑とい党るでしょう。すると金属の 分野でわかっている結晶粒間の緩和現象; 格子欠宿によ る緩和現象も現われるわけで，また柔らかい結晶がこわ れることによる緩和現象む現われて良いはずです。前 2 者の分散は最近二三の人により報告されています5)。し かしながら結晶性高分子の緩和機構に関しては, 無定形 高分子のそれのごとくその機構が明らかとなったとはま だい克ないでしょう。線型の緩和機構が明らかであれば， それをるとにして非線型の領域を調べることができるわ けですが，現在のところ十分な足場ができていない状態 です。さらに無定形高分子の場合, 温度-時間の換算則と いう指導原理がありこのために非常に幅広いデータの 集積がなされたわけですが，結晶性高分子の非線型性沉 扣いては，このような便利なるのがをだなく、求めさな よい女るいている状態です。もしなにか換算則のような ものがあるなら，データも幅広くなり，いろいろの異な った種類の実験の間の関係つけ子なされ，結晶性高分子 の非線型粘弾性についての知見は体系化されるものと思 います。

A：なる倸ど。それではをだ暗やみに光を求めて探 しているという段階ですね。そのかすかな光定具体的比 話してください。 


\section{2. 非線型粘弾性の実験と解析}

B：その前に，どうして結晶性高分子に非線型性が 現われやすいかということに関して，非常に教育的なデ 一タを和見せしましょう。第 1 図(6)は加硫ゴムに充てん

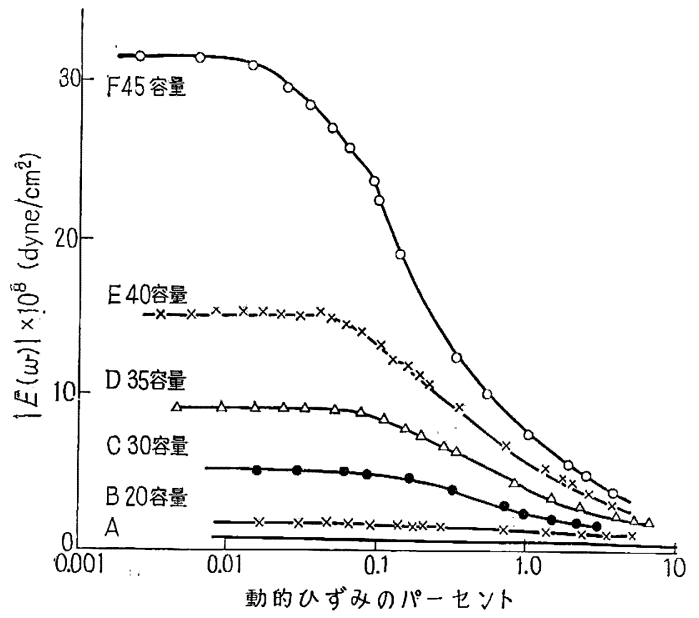

第 1 図

済を容量比 0 ～45\% 末で入れた場合の動的ヤング率を 示するのですが，充てん剂の量が多くなると，ひずみの 振幅が $0.1 \%$ 程度のところから, ヤング率の振幅依存性 がみら机ます。

A：なるほど。教育的だという意味は，これが充てん 剂を結晶性高分子の微結晶になぞら竞たモデル実験とで もいいたいわけですね。

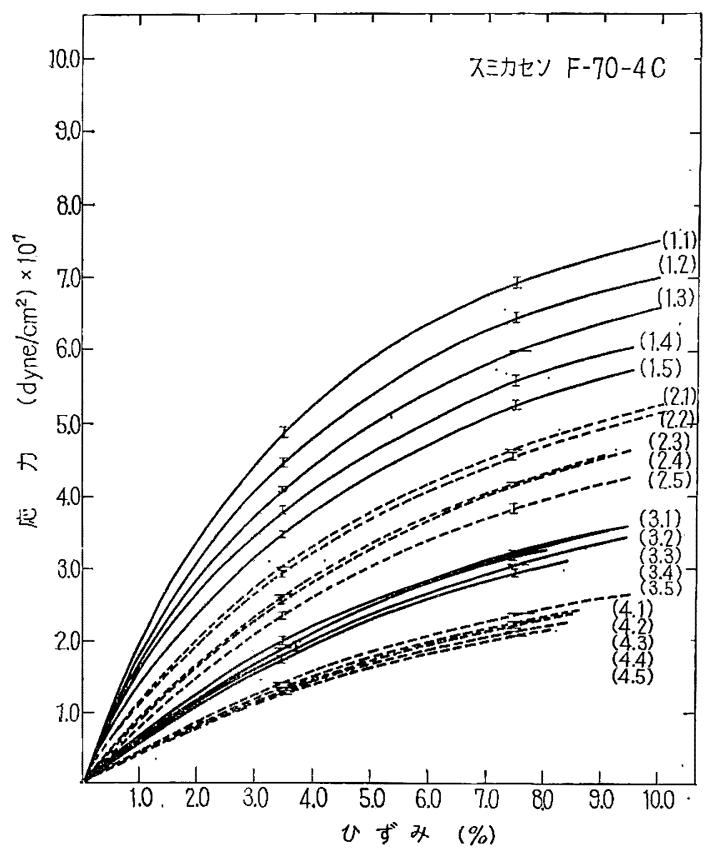

第 2 図
B： まさにそのと㧍りです。もちろん詳しい対応を つ忷ることはできませかが，結晶性高分子内の微結晶と その柔らかさがこの場合の充てん郕とその結合の弱さに

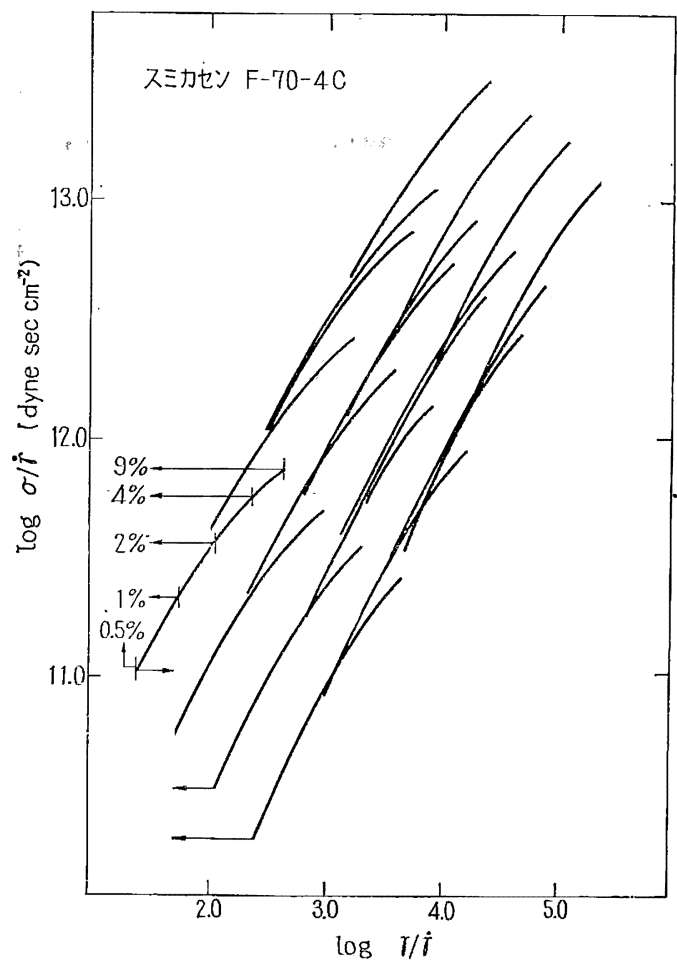

第 3 図

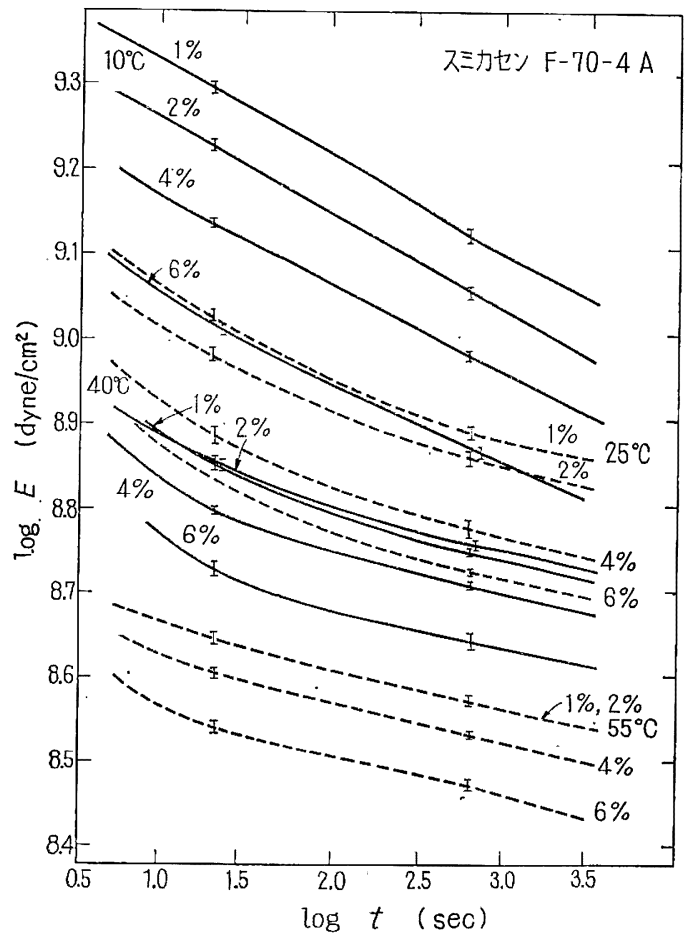

第 4 図 
一応対応しているといえましょう。

A：結晶性高分子でも，ひずみが $1 \%$ 以下ですでに非 線型が現われるのですか。

B: ここに高王法ポリエチレン（スミカセン）の応力 ひずみ曲線がありますが(第2図) $)^{7)}$ ，これをもとにして何 \%のひずみで非線型が現われるかを調べてみなしょう。 図中 $(i, j)$ の $i$ は $1,2,3,4$ で $10^{\circ}, 25^{\circ}, 40^{\circ}, 55^{\circ} \mathrm{C}$ の 実験を, $j$ は $1,2,3,4,5$ で $9.5 \times 10^{-3}, 2.3 \times 10^{-3}, 7.9 \times$ $10^{-4}, 4.8 \times 10^{-4}, 1.6 \times 10^{-4} \% / \mathrm{sec}$ のひずみ速度を表わし ております。線型の場合には Maxwell 模型を用いると， 応力 $\sigma$, ひずみ $\gamma$, 一定ひずみ速度 $\dot{\gamma}$ の間に $\sigma / \dot{\gamma}=\eta\{1-$ $\exp (-r / \dot{r} \tau)\}$ なる関係があり女す。したがって $\sigma / \dot{\gamma} \sim \gamma / \dot{\gamma}$ 曲線は $\dot{\gamma}$ によよません。第 2 図から求めた $\sigma / \dot{\gamma} \sim \gamma / \dot{\gamma}$ 曲線が第 3 図です。図中ひずみを％で表わしてありま す。すでに $1 \%$ のひずみで各温度の煤線群の包絡線より はずれて和ります。この図では温度の高い下の曲線群ほ ど非線型が少なくなって扣ります。

A：第 4 図はポリエチレンの応力緩和ですね。ここ では始めの引伸し率に対する非線型性がむしろ低温で大 きくなっています杖これは緩和により試料の温度が上 がり，そのために見かけの非線型性が現われたと考える ことはできせんか。そうすると温度時閵の換算則でデ 一タを整理できそうですが。

B：たしかに一応誰でも考光てみることですが，ポリ エチレンの応力緩和の場合 $6 \%$ の初わの引伸しに要し た仕事が熱に全部変わったとしても，1゚゚ぐらいの温度

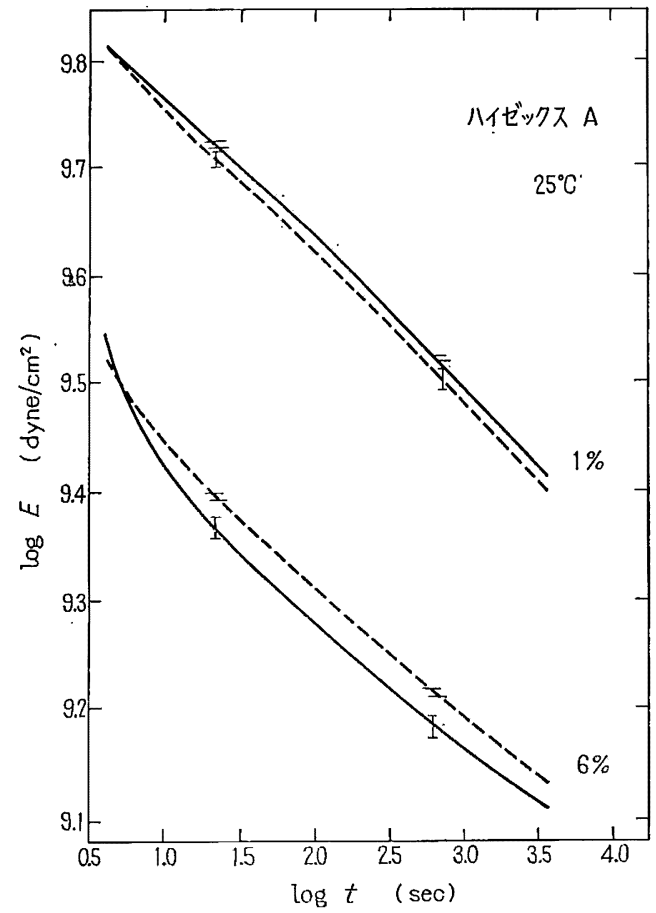

第 5 図
上昇しか女りません。実際に試料のまわりの熱伝達率を゙ 非常に変えた実験（第 4 図は空気中，第 5 図は流動して いる液体中）をしてみましても，第 5 図にみるように，ほ とんどかわりがありません（点線は水の中）。またあなた： の怙考えでは弾性率の大きいものほど非線型性が大きく なるわけですが，テトロンの例では逆です。第 6 図〜第 9 図 $^{8)}$ がそれで高温ほど非線型が大きく現われておりま to

A：クリープにもやはり非線型が現われるのですか。

B：たとえば第 10 図は, Meredith ${ }^{9)}$ により cgs 単.

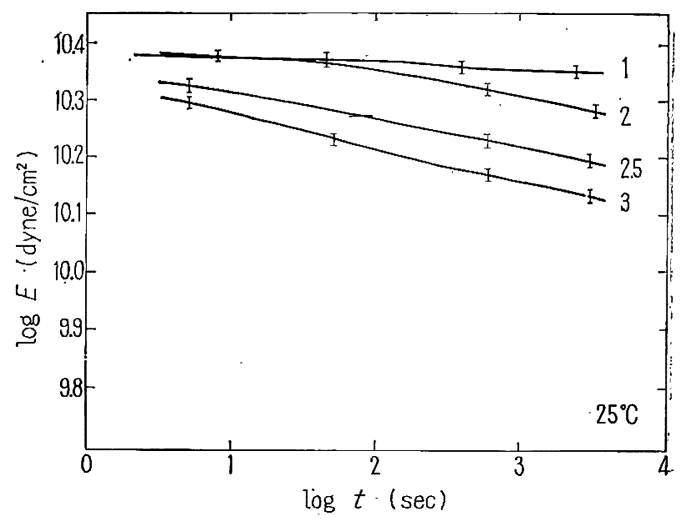

第 6 図

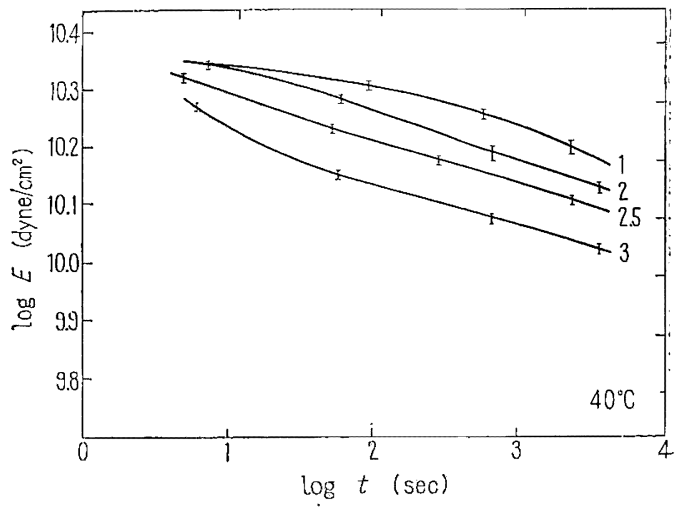

第 7 図

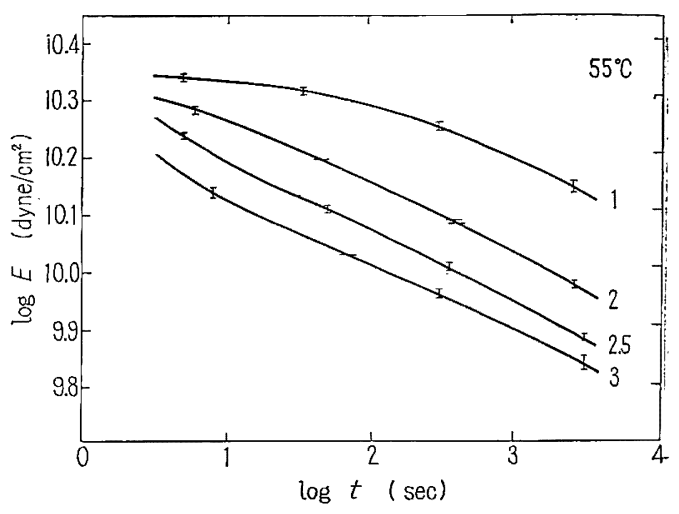

第 8 図 


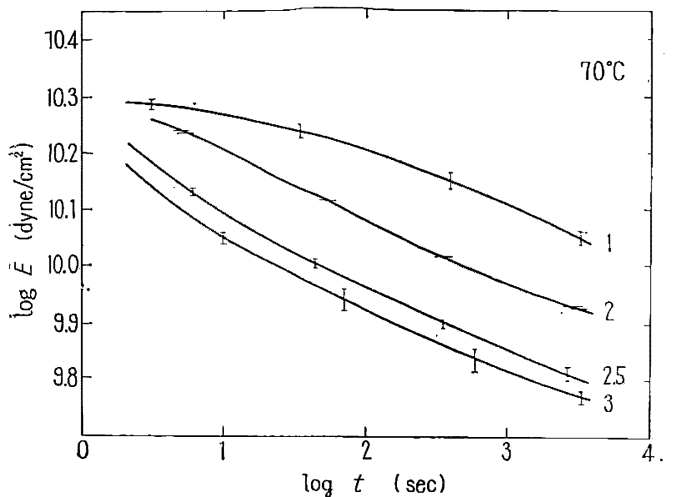

第 9 図

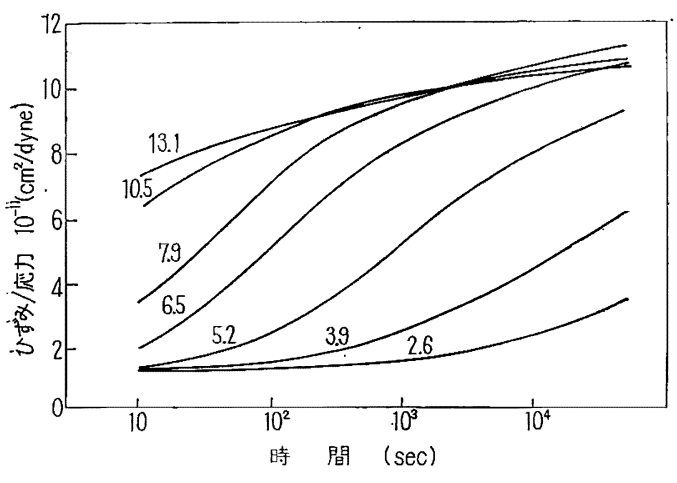

第 10 図

位に書き換えら机た, O’Shaughnessy'10)のビスコースレ ーヨンのクリープのデータです。線型の場合には Voigt 模型について考学ると，ひずみ $\gamma$ と応力 $a$ との間には $\gamma / \sigma=\left(1-e^{-t / \tau}\right) / E$ なる関係があり, $\gamma / \sigma \sim t$ 曲線は応力 $\sigma$ にはよらないはずですが，図でみるように，応力に非常 に関係して扬ります。

$\mathbf{A} ：$ これらの図をみて物りますと，すべて横軸にそ って適当化動かすと重なるような曲線，つまり換算則が :なりたつような曲線にみ充すすね。

B：たしかようなこころみが今までなされて :牧ります。たと克ば第 11 図は Wegener ${ }^{11)}$ によるビス :コースレーヨン，セルロースアセテートの応力緩和曲線

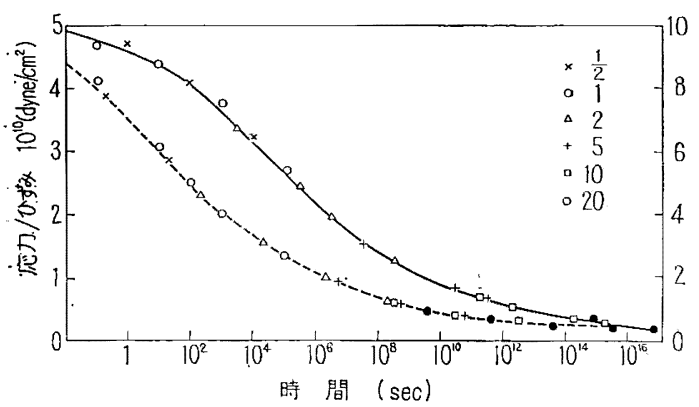

第 11 図
の合成曲線で，そ㞦ぞれ $26 \sqrt[3]{\log (1+\gamma)} ， 12 \log \gamma$ た け横軸にそって移動させてまとめたものです。また第 12 図はCatsiff など(2)の 66 ナイロンに関する合成クリー プ曲線です。

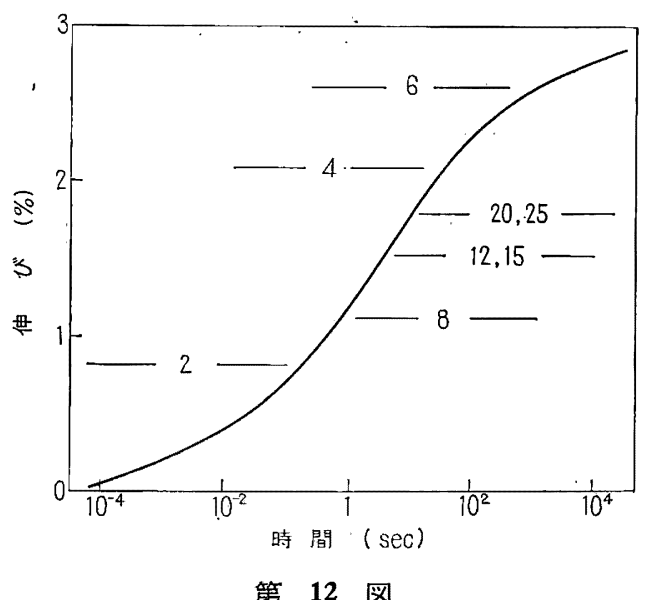

A：なるほどりっぱな曲線が得られていますね。し かしそのような移動についてなんらかの理論的な根拠が ありますか。

B：このような合成曲線が得られるであろう理由は， 自由体積の変化に非線型性の原因があるとする考方方に より理論づけれると思います。自由体積の理論という のは, 低分子の粘性について Doolittle ${ }^{13)}$ が提出したも ので, $\eta=A \exp (1 / f)$ であるとするものです。ここに $f$ は自由体積の比体積に対する比で女ります。この式は高 分子についてもよくあてはまり, 無定形高分子の換算則 にも重要な役割を果たして扣ります。今高分子の一方向 に張力 $\sigma$ が働いたとするとポアソン比 $\mu$ が $1 / 2$ に等し くない場合には張力による体積の変化が生じます。これ は自由体積が変化することで，たとえば張力により自由 体積が大きくなれば，セグメントは動きやすくなり，粘 度は低下するはずです ${ }^{14)} 。 f=f_{0}+B \sigma(1-2 \mu)$ と考圥られ ますから，粘度に比例する緩和時間 $\tau$ は， $\tau=\tau_{0} \exp \{1 /$ $\left.\left(f_{0}+B(1-2 \mu) \sigma\right)\right\}$ となり， $\sigma$ が大きくなると $\tau$ は短く なります。Voigt 模型によると $\gamma=\sigma\left(1-e^{-t / \tau}\right) / E$ ですか ら，これに $\tau$ を代入し李すと， $\sigma^{*}$ を基準とした合成ク リープ曲線が次のごとき操作により得られるはずであり

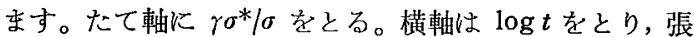
力 $\sigma$ に関するクリープ曲線を横軸にそって $\log a_{\sigma}$ だけ 動かす。ここに

$$
\log a_{\sigma}=-\frac{\left(\frac{1}{2.303 f^{*}}\right)\left(\sigma-\sigma^{*}\right)}{\frac{f^{*}}{B(1-2 \mu)}+\left(\sigma-\sigma^{*}\right)}
$$

であります。 $f^{*}$ は張力 $\sigma^{*}$ の場合の自由体積の割合を表 わします。 
また応力緩和曲線に対しては， $f$ を初めの引きのばし $\gamma$ で展開し，一次の項までとれば，同じょうな換算則が 得られ， $\log t$ 軸にそっての移動により合成曲線が得ら

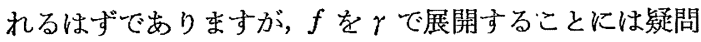
があり，やはりこの場合も $\sigma$ で展開すべきで，そうす ると $\sigma \sim t$ の関係を決める微分方程式は非線型になり，上 のような簡単な换算則はなりたたないことになります。

A：自由体積の理論というと, 結局緩和現象を記述 する2 要素, バネとダッシュポットの中, 後者をいじる ことですね。非線型の粘性については Eyring の hyperbolic 則があります权。

B：10 年前 Eyring ${ }^{15)}$ 一派沈より, hyperbolic 則 による非線型粘弾性の解析が行なわれて拉ります実際 hyperbolic 則は，応力により適当なパラメーターをとれ ば，結晶性高分子の非線型を表わすと十分な粘度变化を 起こすことができるす。

A：バネをいじる考克方はありませんか。

$\mathbf{B}$ ：私達の考宎むしたのは直接バネをいじるわけで はないですが，構造変化に非線型性の原因があるとする 考之です。結晶性高分子の微結晶は比較的柔らかく, し かも高分子の特性として無定形部分とのつながりもある から，比較的小さな外力により変形，あるい恔換が起 こりらるものと考光られます。これらを外力により $\mathrm{A} \rightarrow$ B にかわると考觉すを，その機構は明らかではありま せんが，非線型の原因になりらるわけです。実際複屈折， $\mathrm{X}$ 線などにより，外力による結晶の回転， $\mathrm{C}$ 軸の配向 ${ }^{16)}$ などが報告されて物りますし，電子顕徽鏡により結晶の ほどけ17も報告されて和ります。

ここでは第 13 図のような結晶のほどける模型18)を用

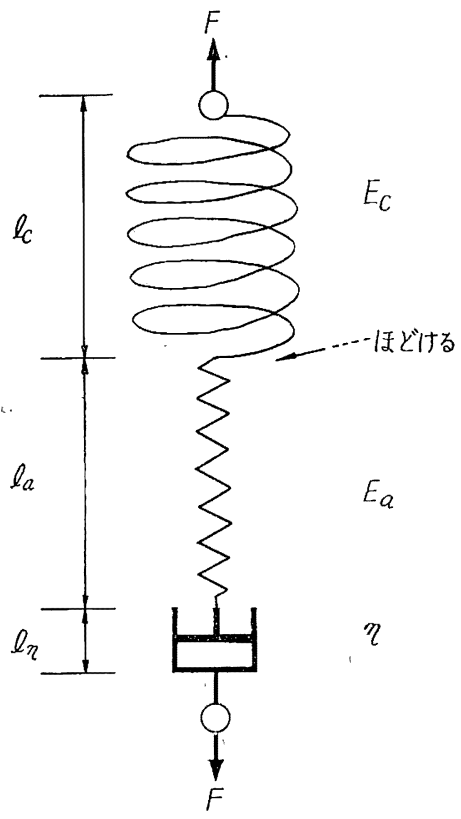

第 13 図
いますがこれれは結晶が回転するとしても同じょうな傾 向がでてきすす。 $l_{c}, l_{a}, l_{\eta}$ は結晶, 無定形バネ, ダッシ ニポットの時刻 $t$ に就ける長さであり， $t=0$ ではそれ ぞれ $l_{c 0}, l_{a 0}, l_{\eta_{0}}=0$ です。 $E_{c}, E_{a}, \eta$ はそれぞれの弾性率 および粘性率です。結晶部分と無定形部分の境目がほど けるとします。ほどけた結晶部分は る無定形部分になるとしをす。外力を $F$ としますと” カのつり合いの式は

$$
\left.\begin{array}{l}
\left.\eta l_{\eta}=F=\frac{E_{a}\left\{l_{a}-\left(l_{a 0}+\alpha \xi\right)\right\}}{l_{a 0}+\alpha \xi}=\frac{E_{c}\left\{l_{c}-\left(l_{c 0}-\xi\right)\right\}}{l_{c 0}-\xi}\right\} \\
\dot{\xi}=\kappa F
\end{array}\right\}
$$$$
\text { となり, } F=E \Delta L / L_{0}\left(\Delta L=L-L_{0}=\left(l_{a}+l_{c}+l_{\eta}\right)-\left(l_{a 0}+l_{c 0}\right)\right)
$$
に従い, 応力緩和のみかけのヤング率 $E$ 䘮近似的に求 めると,

$$
\begin{aligned}
E= & \frac{E_{a}\left(\frac{1}{\kappa \eta}+\alpha-1\right)}{\frac{l_{a 0}}{L_{0}}\left(\frac{1}{\kappa \eta}+\alpha-1\right)+\alpha \frac{\Delta L}{L_{0}}} \\
& \exp \left\{-\frac{\kappa \frac{E_{a}}{L_{0}}\left(\frac{1}{\kappa \eta}+\alpha-1\right)^{2} t}{\frac{l_{a 0}}{L_{0}}\left(\frac{1}{\kappa \eta}+\alpha-1\right)+\alpha \frac{\Delta L}{L_{0}}}\right\}
\end{aligned}
$$

となり， $1 \%$ の引伸しのヤング率を $E_{1}, x \%$ のものを $E_{x}$ とすると， $E_{x}$ は $\log E$ 柿よび $\log t$ 軸炕そって, それぞれ，

$$
D=\log \frac{\left\{\frac{l_{a 0}}{L_{0}}\left(\frac{1}{\kappa \eta}+\alpha-1\right)+\alpha x\right\}}{\left\{-\frac{l_{a 0}}{L_{0}}\left(\frac{1}{\kappa \eta}+\alpha-1\right)+\alpha\right\}}
$$

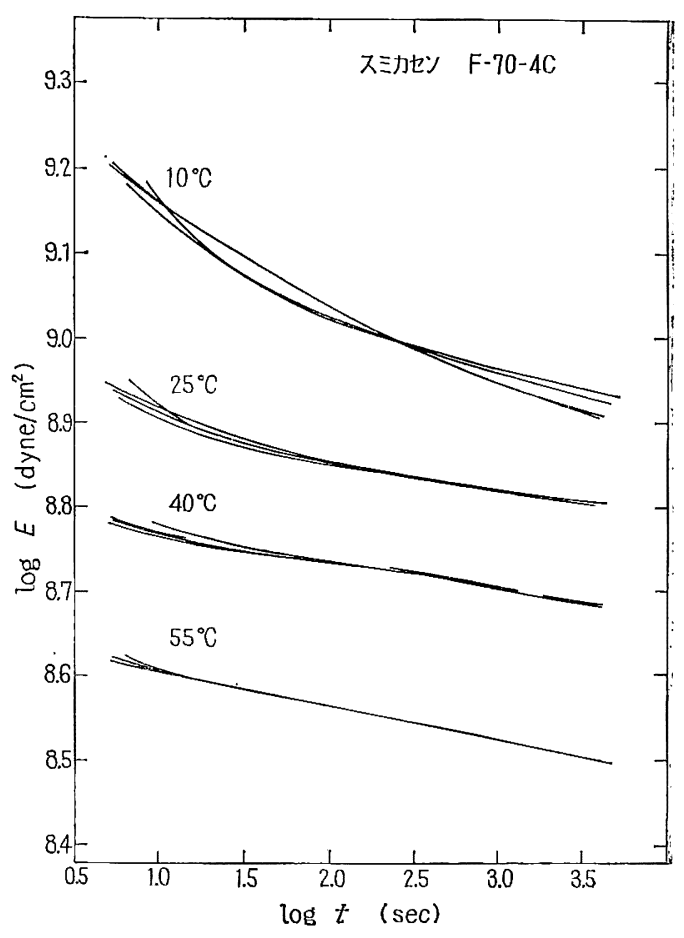

第 14 図 

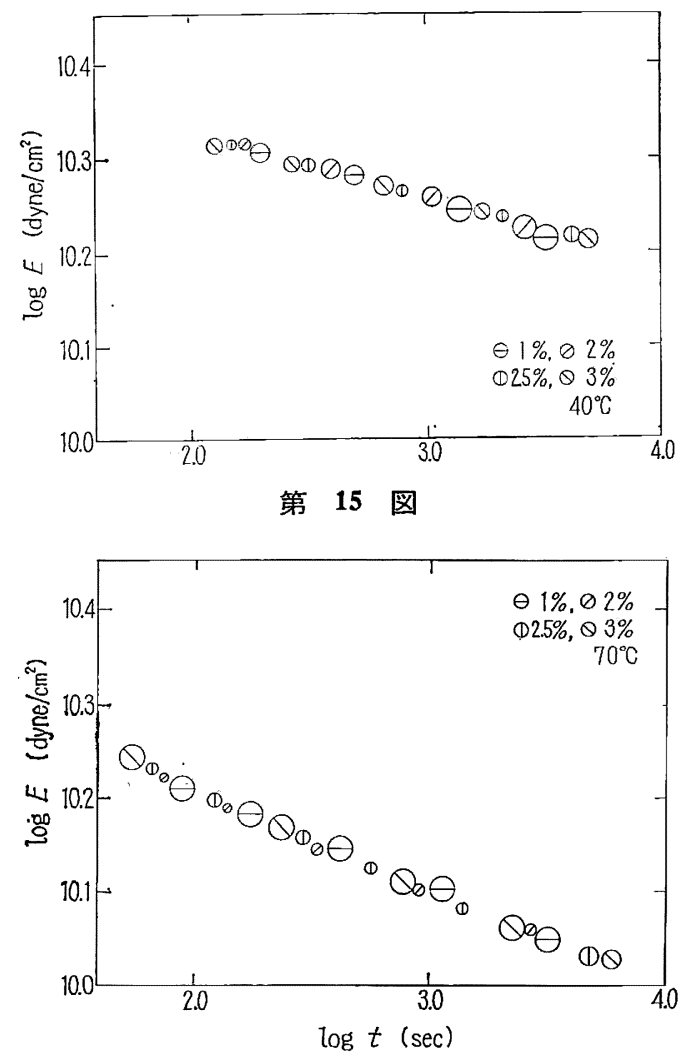

第 16 図

だけ動かすと， $E_{1}$ と重なることがわかりすす。第 14 図は第 4 図のデータを，第 15,16 図は第 7,9図のデータ をこの方法により重ねたものです。重ねるときの移動量

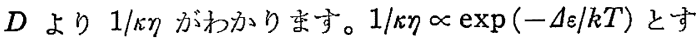

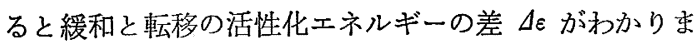
す。ポリエチレンについては $\Delta \varepsilon=6.2 \pm 0.8 \mathrm{kcal} / \mathrm{mol}$, テ トロンについては $\Delta \varepsilon=-(0.60 \pm 0.54) \mathrm{kcal} / \mathrm{mol}$ を得ま す。 $\Delta \varepsilon$ の值は線型の応力緩和曲線と関係があるようで, ポリエチレンタ低温では $\Delta \varepsilon<0$ となり，テトロンであ 高温では $\Delta \varepsilon>0$ となることが想像されすす。線型の性 質自身が $\mathrm{A} \rightarrow \mathrm{B}$ の移り変わりにあるようにも思われる のです。第 13 図恬結晶のほどける模型でありますが, 結 晶の回転に上る模型を用いても， $\alpha \rightarrow 0, \kappa \rightarrow-\kappa, \xi \rightarrow$ 一そとすれば同じ式がなりたちおす。この場合 $\xi$ は回 転により外力方向に伸びた結晶の長さであります。

A：温度領域を広げた実験が必要であるととるに，線 型の性質と合わせて考穴ていくことが必要ですね。とこ ろで無定形高分子の解析に重要な役割りを果した Gross の線型の現象論の拡張の試みはないのですか。

B：線型粘弾性の基礎は Boltzmann の式化岁るわ けで,

$$
\sigma(t)=\int_{-\infty}^{t} G_{1}(t-\tau) \gamma(\tau) d \tau
$$

により応力ーひずみの関係が与兄られます。この式は応 力をひずみの函数微分により展開し，その第 1 項をとっ たものと考光られます。非線型に拡張するには高次の項 までとればよいわけで,このような線にそって高次の余 効函数 $G_{n}$ を調べる研究が中田, 岡野19)によりなされ ました。この研究によると, たとえば応力緩和, クリ一 プなどの余効函数の間の関係孞わかりますので，適当な 実験があればそれらを実証することができるわけです。 実際中田 ${ }^{201}$ とよりその試みがなされたのですが，幅広い データがないために成功して和りなせん。この展開は， たとえば応力緩和の場合には

$$
\sigma=A \gamma+B \gamma^{2}+C \gamma^{3}+\cdots \cdots
$$

のごとくなるわけですが，実験にみるように 大きいことは, 展開形式になんらかの工夫が必要かもし れせせん。

A：今まの括話しでは非線型弾性はまだまだですね。 もう少し幅広いデータの集積がたしか沉必要ですね。

B：非線型粘弾性は，ここに主に述べた中変形から， さらに大変形，破断に至るまでありまして，これらを一 貫してまとめあげることはたいへんなことです。とにか く系統的な幅広いデータの集積が必要です。

\section{文献}

1) B. Gross: "Mathematical Structure of the Theories of Viscoelasticity", Hermann and $\mathrm{C}^{\mathrm{1e}}$, Paris (1953)

2) J. D. Ferry et al: J. Am. Chem. Soc., 72, 3746 (1950); A. V. Tobolsky, J. R. McLoughlin : $J$. Polymer Sci., 8, 543 (1952)

3）たと党ば J. G. Kirkwood：Rec. Trav. Chim., 68, 649 (1949); P. E. Rouse: J. Chem. Phys., 21, 1272 (1953)

4) “高分子の物性”, 化学同人

5) M. Takayanagi et al: J, Polymer Sci., 46, 531 (1960); 和田八三久, 日本物理学会年会講座 (1962)

6) A. R. Payne: J. Appl. Polymer Sci., 3, 127 (1960)

7) T. Takemura, M. Kuroki : Reports on Progress in Polymer Physics in Japan, 4, 55 (1961); 5, 159 (1962)

8) M. Kuroki, T. Takemura: Reports on Progress in Polymer Physics in Japan, 4, 59 (1961)

9) R. Meredith: "Rheology" Vol. II, 261, Eirich 編, Academic Press (1958)

10) M. T. O'Shaughnessy: Text. Res. J., 18, 263 (1948)

11) W. Wegener: Melliand Textilberichte, 30, 90, 138, 184, 229, 282, 388, 443, 501, 558 (1949)

12) E. Catsiff, T. Alfrey, M. T. O'Shaugnessy: Text. Res. J., 23, 808 (1953)

13) A. K. Doolittle: J. Appl. Phys., 22, 1471 (1951); 23, 236 (1952)
(81 ページヘつづく) 
9）加納夏樹, 東村敏延, 岡村誠三：Makromol. Chem., 投稿中

10）東村敏延, 今西幸男, 米沢貞次郎, 福井謙一, 岡村 誠三：Polymer, 3, 167 (1962)

11) D. J. Worsfold, S. Bywater: J. Chem. Soc., 1960, 5234

12）岡村誠三，東村敏延，浜田隆樹：第 11 回高分子 年次大会 (1962)

13) R. J. Orr: J. Polymer Sci., 58, 843 (1962)

14) D. C. Pepper: Trans. Faraday Soc., 45, 397 (1949)

15) L. Ambroz, Z. Zlámal: J. Polymer Sci., 30, 381 (1958) その他

16) 岡村誠三，東村敏延：第 9 回高分子年次大会 (1960)

17) D. J. Metz: J. Polymer Sci., 50, 497 (1961)

18) M. Morton, E. E. Bostick, R. Livigni : Rubber \& Plastic Age, 42, 397 (1961)

19) G. Gee, W. C. E. Higginson: J. Chem. Soc., 1959, 1338, 1345

20) K. Veselý : J. Polymer Sci., 52, 277 (1961); International Symposium on Makromol Chem., (1961)

21）岡村誠三，東村敏延，冨川昌也：工化， 65, 711 (1962)

22）岡村誠三, 東村敏延, 武田啓扶：Makromol. Chem., 51, 217 (1962)

23）たとえば, 東村敏延, 児玉恒雄, 岡村誠三：高化, 17, 163 (1962)

24）岡村誠三, 東村敏延, 渡辺俊経：Makromol. Chem., 50, 137 (1961)

25）たとえば，岡村誠三，東村敏延，中山博之，田中

（竹村哲男 黑木仁昭著「結晶性高分子の非線型粘弾 性」の 87 ページよりのつづき)

14) J. D. Ferry, R. A. Stratton: Kolloid-Z., 171, 107 (1960)

15) A. V. Tobolsky, H. Eyring: J. Chem. Phys., 11, 125 (1943); H. Eyring, G. Halsey: The Mechanical Properties of Textiles in "High Polymer Physics", 98, Chemical Publishing Co., Inc., New York

16) A. V. Tobolsky: Text. Res. J., 19, 8 (1949);
厚生, 岩佐一郎：第 11 回高分子年次大会 (1962)

26) G. Natta : J. Polymer Sci., 48, 219 (1960); 51, 487 (1961)

27) D. Braun, M. Herner, U. Johnsen, W. Kern : Makromol. Chem., 51, 15 (1962)

28) H. Staudinger: Ann. 517, 73 (1935)

29) J. P. Kennedy, R. M. Thomas: Makromol. Chem., 53, 28 (1962)

30）たと党ば, N. G. Gaylord, H. F. Mark： “Linear and Stereoregular Addition Polymers." Interscience (1959)

31) (a) D. S. Breslow, G. E. Hulse, A. S. Matlack: J. Am. Chem. Soc., 793760 (1957)

(b) 岡村誠三, 東村敏延, 妹尾忠雄: 日化第 15 年 会 (1962)

32) G. Natta, G. Mazzanti, G. F. Pregaglia, G. Pozzi : J. Polymer Sci., 58, 1201 (1962)

33) B. Eisler, S. D. Farvsworth, E. Kendrick, R. Schnurmann, A. Wassermann : J. Polymer Sci., 8, 157 (1952)

34）たとえば, T. Imoto, T. Matsubara： J. Polmer Sci., 56, S 5 (1962)

35) A. G. Evans, M. Polanyi : J. Chem. Soc., 1947, 252

36) L. Höhr, H. Cherdron, W. Kern: Makromol. Chem., 52, 59 (1962)

37) R. C. Bubbon, D. Margerison: J. Chem. Soc., 1960, 146

38）たとえば，G. Natta, M. Peraldo, M. Farina, G. Bressan: Makromol. Chem., 55, 139 (1962)

39) G. Natta, F. Danuso, D. Sianesi: Makromol. Chem., 30, 238 (1959)

S. L. Aggarwal, G. P. Tilley, O. J. Sweeting: J. Appl. Polymer Sci,. 1, 91 (1959); R. S. Stein: J. Polymer Sci., 34, 709 (1959)

17）“高分子の物性”，11，高分子の電子顕微鏡による 構造研究, 化学同人

18) T. Takemura, M. Kuroki: 前出

19) O. Nakada: J.Phys. Soc.Japan, 15, 2280 (1960); K. Okano, O. Nakada: J. Phys. Soc. Japan, 16, 2071 (1961)

20）日本物理学会 17 回年会

\section{研究論文集「高分子化学」内容紹介}

第 19 巻. 第 211 号・ 1962

本誌は高分子物理, 化学, 基礎工 学をはじめ，広く高分子の全城に わたるオリジナルの論文を網羅集 録して招ります。

[物 理]

〔103〜104] ポリブテンー1 の結晶化度と立体規則性に関する研究

第 1 報 結晶化度。

第 2 報 立体規則性

[化 学]

〔105〕 アルデヒド共存下で重合したポリ酢酸ビニルおよびポリビニルアルコールの末端カル

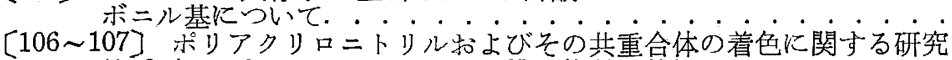

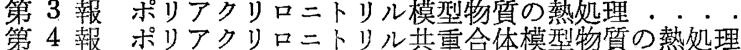

[108]泉オリグニンと合成ゴムとの結合に関する研究

第 7 報 $\mathrm{pH}$ によるチオリグニンの分別と各フラクションの SBR 補強性について

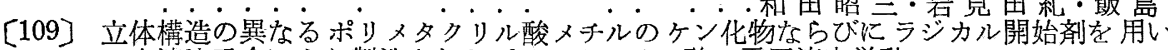

て水溶液重合により製造されたポリメタクリル酸の電圧滴定挙動

“Die makromolekulare Chemie” (Band 55, 1962) 掲載論文の要旨 